\title{
Conservation Agriculture and Household Wellbeing: A Non-Causal Comparison among Smallholder Farmers in Mozambique
}

\author{
W. E. McNair ${ }^{1}$, D. M. Lambert ${ }^{2} \&$ N. S. Eash ${ }^{3}$ \\ ${ }^{1}$ United States Soybean Export Council, St. Louis, MO, USA \\ ${ }^{2}$ Department of Agricultural \& Resource Economics, University of Tennessee Institute of Agriculture, Knoxville, \\ Tennessee, USA \\ ${ }^{3}$ Department of Biosystems Engineering \& Soil Science, University of Tennessee Institute of Agriculture, \\ Knoxville, Tennessee, USA \\ Correspondence: D. M. Lambert, Department of Agricultural \& Resource Economics, 2621 Morgan Circle, \\ University of Tennessee Institute of Agriculture, Knoxville, Tennessee, 37996, USA. Tel: 1-865-974-7472. \\ E-mail: dlamber1@utk.edu
}

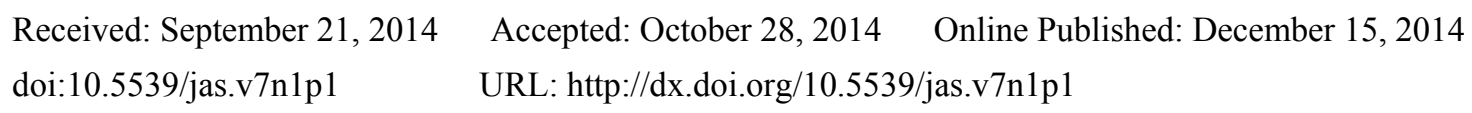

\begin{abstract}
This research examines the relationship between household wellbeing and the use of conservation agriculture (CA) by smallholder farmers in Mozambique. Wellbeing indicators are regressed on household demographic attributes, farm management practices, and a variable indicating farmer adoption of CA. Findings suggest that households using CA have higher wellbeing index scores related to farm tool and implement ownership and housing material quality, but lower index scores related to livestock ownership. The findings present an encouraging, baseline picture of the association between the use of CA technologies by farmers in Mozambique and household wellbeing.
\end{abstract}

Keywords: minimal tillage, residue management, survey, Southern Africa, quality-of-life indexes

\section{Introduction}

In recent years, governments and non-governmental organizations have promoted conservation agriculture (CA) practices, including no-till, residue management, and crop rotation in Mozambique. From an agronomic perspective, CA stabilizes or increases maize yields and conserves soil and water resources on vulnerable agricultural land. From a socioeconomic perspective, the adoption of CA could increase household income and wellbeing, decrease gender equity gaps, and enhance food security.

Soil degradation is an economic and environmental concern for the government and people of Mozambique. Most rural households depend directly on agriculture for food and income. Smallholder agriculture dominates Mozambique's agricultural sector, employing $90 \%$ of the population in the north-central region of the country (Mozambique Ministry of State Administration 2005). Maize is the primary staple crop consumed in Mozambique, accounting for at least 50\% of the caloric intake (Erenstein, 2003; Ekboir, 2002). The average farm size in Mozambique is 2.4 hectares; $98 \%$ of agricultural production occurrs on farms less than five hectares (Falcão, 2009; Heltberg \& Tarp, 2002). Irrigation is limited because of pumping costs and groundwater scarcity; about $86 \%$ of agricultural production depends on seasonal rains (Almeida, Rucker, Gemo, \& Launchange, 2009).

Labor-intensive cultivation and relatively low yields characterize conventional maize farming in Mozambique. Maize production using conventional practices usually entails clearing or burning in situ crop residue. Farmers typically use the moldboard plough when they have access to livestock to prepare land for planting. In northern Mozambique a land management system based on ridges and furrows is a common adaptation to heavy rains $\left(>1500 \mathrm{~mm} \mathrm{yr}^{-1}\right)$, but this system may lead to waterlogging problems. Farmers feed agricultural residues to livestock. Some residues are used for cooking. Anecdotally, the main reasons given by farmers for tilling is to control weeds and incorporate the ashes of burned shrubs, aerate soils, and prepare a fine soil tithe before planting. Only $16 \%$ of farmers hire labor to work on fields (Sitoe, 2005). Very few farmers own tractors, and only $11 \%$ of the fields in Mozambique are cultivated using animal traction (Almeida et al., 2009; Sitoe, 2005). Maize yields of conventional production systems range between 0.4 and 1.3 metric tons ha ${ }^{-1}$, partly due to the 
relatively limited use of fertilizers or improved maize varieties (Howard, Kelly, Maredia, Stepanek, \& Crawford, 1999). Only about $4 \%$ of farmers use commercial mineral fertilizers (Almeida et al., 2009; Morris, 2007; Uaiene, 2008). When mineral fertilizer is used, it is usually under-applied at rates of $3.2 \mathrm{~kg} \mathrm{ha}^{-1}$, which is approximately $5 \%$ of the fertilizer rate that would be recommended. Pesticide and herbicides are used by $6.7 \%$ of farmers (Sitoe, 2005).

About $51 \mathrm{~kg} \mathrm{ha}^{-1}$ of soil nutrients is lost per year from erosion caused by plowing or tilling in Mozambique (Morris, 2007), a rate that is nearly fifteen times higher than nutrients applied through fertilization. Conventional agronomic practices expose soils to heavy rains and sun, exacerbating water and wind erosion and higher water evaporation losses. Lower yields caused by soil degradation results in maize supply shortages and higher prices in the short term. In the long term, chronic soil erosion leads to desertification, food insecurity, social instability, and higher poverty rates among smallholder farmers (FAO, 2001a). In response, international non-governmental organizations and domestic and foreign government agencies have supported efforts to promote the sustainable intensification of agricultural production based on conservation agriculture (CA) systems.

There are three guiding principles of CA; 1) minimum soil disturbance (e.g., no-till or direct planting of seed); 2) permanent organic soil cover with plant residues; and 3) crop rotations and/or the use of green manure cover crops (Thierfelder \& Wall, 2009). Planting maize or sorghum in previously dug basins is common in some areas (Silici, Ndabe, Friedrich, \& Kassam, 2011). These basins are typically $15 \mathrm{~cm} \times 15 \mathrm{~cm} \times 7.5 \mathrm{~cm}$ and are dug during the winter season or at the onset of the rainy season (Johansen, Haque, Bell, Thierfelder, \& Esdaile, 2012). Other common planting methods are direct seeding using jab planters or pointed sticks (i.e., 'dibble sticks') or, in the case of having access to draft animals, no-till planters. Farmers adopting CA are encouraged to prevent animals from grazing on fields and encouraged to plant cover crops for greater soil cover (Grabowski, 2011; FAO, 2012). Recent research in the region continues to demonstrate that conservation agriculture reduces soil erosion, enhances soil fertility, stabilizes yields, and increases input use efficiency and water infiltration rates (Kassam, Friedrich, Shaxson, \& Pretty, 2009; Thierfelder, Cheesman, \& Rusinamhodzi, 2013; Ngwira, Aune, \& Mkwinda, 2012).

In addition to agronomic benefits, CA systems may also increase farm household wellbeing through higher income, input cost savings, or food security (For a critical assessment of CA in general, refer to Giller, Witter, Corbeels, and Tittonell (2009) and Giller (2012)). Ngwira, Thierfelder, Eash, and Lambert (2013) found that profits for maize produced under CA systems were $61 \%$ to $116 \%$ higher than profits produced by conventional tillage practices ( $\$ 344 \mathrm{ha}^{-1}$ ). Mazvimavi and Twomlow (2009) and Guto, Pypers, Vanlauwe, de Ridder and Giller (2011) found that profit margins for crops produced with minimum tillage technologies were superior to net returns produced under conventional systems. Ngwira et al. (2013) found that risk-averse farmers preferred CA systems compared to conventional tillage systems, with risk premiums for conservation agriculture systems (relative to conventional farming methods) ranging between \$40 and \$105 US dollars. Most of these studies compared the profitability of CA systems with conventional farming practices using partial budget analysis (e.g., Boehlje \& Eidman, 1984). The vast majority of this work has been conducted in southern Africa.

Yet, as Thierfelder, Mwila, and Rusinamhodzi (2013) indicate, the impact CA systems have on household economic standing and household wellbeing remains unstudied. This is partly due to the challenges of measuring the impact of conservation agriculture on household income and/or wellbeing including the time horizon over which the intervention is introduced, the intensity of adoption or abandonment of the technology by target groups, partial adoption of technologies, farmer recall of yield and business transaction records, non-monetary transactions between households, and the nexus of factors codetermining household wealth or farm family wellbeing.

This paper applies indices to proxy household wellbeing, comparing them between households that were practicing CA during the time of the survey with the wellbeing of other households. Indices are used to proxy household wealth and wellbeing when household income and consumption expenditures are difficult to measure (Howe, Hargreaves, \& Huttly, 2008; Montgomery, Gragnolati, Burke, \& Paredes, 2000; Moser \& Felton, 2007; Vyas \& Kumaranayake, 2006). Common proxies for household wellbeing include ownership of physical assets such as durable goods; fertility, mortality, and morbidity; wage earnings; materials used to build houses; access to sanitation; and the purchase of durable goods (Boserup, 1985; Howe et al., 2008). Other indirect measures of wellbeing and wealth include gender empowerment, economic opportunity, and social standing (Montgomery et al., 2000). Indices measuring household wellbeing among smallholder farmers typically include information about the quality of house construction materials, food and water resources, and asset and livestock ownership (Silici 2010; Filmer \& Pritchett, 2001). This study applies three indices to proxy household wellbeing and wealth in terms of livestock ownership $\left(I^{L}\right)$, the ownership of farm tools and implements $\left(I^{A}\right)$, and the quality of 
materials used to build houses $\left(I^{C}\right)$.

The correlation between the indices and the use of CA is determined and conditioned on household demographic characteristics and farming practices. The indices proxy relative socioeconomic status in terms of ownership of farm tools and implements, livestock, and the quality of materials used to build houses. Of particular interest are comparisons among three groups: 1) households that practiced CA; 2) households that used conventional tillage practices in communities where CA had been introduced by extension efforts; and 3) households in communities where CA had not yet been introduced. The index distributions of each group are compared using standard univariate statistical procedures and multivariate regression analysis. Univariate comparisons are important in this respect for identifying differences between levels of these indicators between household groups. Yet, the interconnections between wellbeing, farm and farmer attributes, technology use, market access, and agricultural training are complex, calling for a systematic representation of these linkages. The empirical analysis is formulated as a multivariate correlational analysis, focusing on the interaction between the indices, demographic attributes, and the use of CA. Holding other factors constant and keeping in mind the cross-sectional nature of the survey data, the primary focus of this analysis is to determine if the average of the wellbeing indices considered here are higher for households practicing CA compared with other households producing maize using conventional practices. Conditioning the indices on household demographic attributes and respondent characteristics provides a ceteris paribus comparison of CA use by households and household wellbeing; important details for establishing benchmarks measuring the medium to long term effects of CA on household wellbeing.

\section{Method}

\subsection{Household Survey}

The household survey was conducted in the Angonia, Tsangano, and Barue Districts, Mozambique, March 2012. These districts were selected as the primary survey area because of ongoing efforts to promote the adoption of $\mathrm{CA}$ in these regions by non-government organization (NGO) and the Mozambican Government Ministry of Agriculture (MAG). In the Angonia and Tsangano districts, the sample of villages ( $n=14)$ was located between the provincial capital of Ullongue and near the Malawi border. In the Barue districts, villages were located around the provincial capital, Barue $(n=8)$. Candidate survey villages were located within 30 kilometers of the provincial capitals of each district. Trained enumerators used a survey instrument to collect information about household demographic attributes, farm production characteristics, access to/participation in markets, and previous experience with CA.

The survey design provides an opportunity to establish a baseline comparison of the wellbeing of households practicing CA relative to other households within and outside their community. Farmers practicing CA managed one or more fields (on average, farmers owned 2.3 fields, with a total average of 1.67 hectares in land holdings) where at least $25 \%$ of the field surface was covered with crop residue, and had planted maize using no-till technologies including basins, dibble sticks, or jab planters. In the Agonia and Tsangano districts, seven communities were selected from the set of communities where NGO and MAG extension agents had promoted no-till, crop rotation, and residue management since 2005. We refer to these communities as 'exposed' (exp). Additional communities were identified according to the expert opinion of field technicians, based on the criteria that there had been no previous efforts by NGO or MAG activity in the village promoting CA and their proximity to the exposed villages. Seven communities were randomly selected from this list. We refer to these communities as 'unexposed' communities (unexp). A similar village identification procedure was used in the Barue district, identifying four exposed and four unexposed communities. In Barue, efforts by a different NGO promoting CA had also been ongoing since 2005.

Households not practicing CA in the exposed communities and households in the unexposed communities were identified using a systematic sampling procedure (Lohr, 2010). Community leaders identified village boundaries and indicated which compounds were individual households. When a household head could not be identified or a compound was vacant, enumerators were instructed to flip a coin to survey the previous or next household on their assigned transect. All farmers practicing CA on a list of individuals provided by the NGO representatives were interviewed ( $n=97$ in Angonia and Tsangano, and $n=107$ in Barue, Table 1).

Area sampling intensity was based on community population estimates. Community leaders and NGO extension agents provided village population estimates before the survey was conducted. A margin of error of $8 \%$ (with a $95 \%$ confidence interval) was used to determine sample size in the Angonia and Tsangano districts. For logistical and budgetary constraint reasons, a margin of error of $10 \%$ (with a $90 \%$ confidence interval) was used to determine sample size of the Barue district survey. The sampling intensities of the exposed, but non-CA using 
households and unexposed households were $6 \%$ and $12 \%$, respectively. Of the 5,256 farm households in the survey region, $57 \%$ lived in communities where CA extension efforts were ongoing (Table 1). The survey sample included $n=559$ households; of which 92\% $(n=514)$ were contacted and interviewed. Of these households; 24 $\%$ practiced CA; $42 \%$ lived in villages where extension efforts had occurred, but did not practice CA; and 29\% lived in villages where no extension activities promoting CA had occurred.

Table 1. Survey sample and area population

\begin{tabular}{llll}
\hline & Angonia and Tsangano & Barue & Total \\
\hline Total households in area population & 3,215 & 2,041 & 5,256 \\
& & & \\
Exposed villages & 2,244 & 757 & 3,001 \\
Unexposed villages & 1,068 & 1,284 & 2,352 \\
Practicing conservation agriculture & 97 & 107 & 204 \\
& & & \\
Survey sample total & 365 & 194 & 559 \\
\hline
\end{tabular}

Table 2. Distribution of livestock and asset scores

\begin{tabular}{|c|c|c|c|c|c|c|c|c|c|c|}
\hline \multirow{2}{*}{ Quartile score/sample: } & \multicolumn{10}{|c|}{ Households in each score category } \\
\hline & 0 & $\mathrm{~N}$ & 25 & $\mathrm{~N}$ & 50 & $\mathrm{~N}$ & 75 & $\mathrm{~N}$ & 100 & $\mathrm{~N}$ \\
\hline \multicolumn{11}{|l|}{ Asset index: } \\
\hline Axe & 0 & 182 & . & & 1 & 184 & . & & $\geq 2$ & 92 \\
\hline Hoe & 0 & 3 & 1 & 34 & 2 & 130 & 3 & 228 & $\geq 5$ & 92 \\
\hline Sprayer & 0 & 416 & . & & 1 & 64 & . & & $\geq 1$ & 7 \\
\hline Sickle & 0 & 207 & . & & 1 & 197 & . & & $\geq 2$ & 83 \\
\hline Shovel & 0 & 373 & . & & 1 & 94 & . & & $\geq 1$ & 20 \\
\hline Plow & 0 & 455 & . & & 1 & 23 & . & & $\geq 1$ & 9 \\
\hline Ox Cart & 0 & 436 & . & & 1 & 47 & . & & $\geq 1$ & 4 \\
\hline Wheelbarrow & 0 & 475 & . & & 1 & 11 & . & & $\geq 1$ & 1 \\
\hline Machete & 0 & 353 & . & & 1 & 87 & . & & $\geq 2$ & 47 \\
\hline Motorcycle & 0 & 465 & . & & 1 & 22 & . & & $\geq 1$ & 2 \\
\hline Bike & 0 & 221 & . & & 1 & 201 & . & & $\geq 2$ & 65 \\
\hline \multicolumn{11}{|l|}{ Livestock index: } \\
\hline Chicken & 0 & 193 & 1 & 66 & 4 & 81 & 8 & 67 & $\geq 15$ & 80 \\
\hline Pig & 0 & 413 & 1 & 20 & 2 & 13 & 3 & 27 & $\geq 7$ & 14 \\
\hline Goat & 0 & 282 & 1 & 21 & 3 & 67 & 4 & 76 & $\geq 6$ & 41 \\
\hline Cattle & 0 & 378 & 1 & 11 & 2 & 57 & 3 & 19 & $\geq 6$ & 22 \\
\hline Duck & 0 & 469 & 1 & 1 & 4 & 6 & 5 & 8 & $\geq 7$ & 3 \\
\hline Rabbit & 0 & 458 & 1 & 5 & 3 & 8 & 6 & 4 & $\geq 8$ & 7 \\
\hline
\end{tabular}

\subsection{Household Wellbeing Indices}

Calculation of the livestock and farm asset indices is based on Silici (2010). The livestock index $\left(I^{L}\right)$ measures the relative wealth of respondents in terms of livestock ownership. Livestock are an important indicator of wealth in some sub-Saharan African cultures (Evans-Pritchard, 1953). The livestock index is calculated using six variables indicating ownership of chickens, pigs, goats, cattle, ducks and rabbits (Table 2). The farm asset index 
$\left(I^{A}\right)$ measures relative household wealth in terms of farm tool and implement ownership, and is based on the ownership of axes, hoes, backpack sprayers, irrigation pumps, sickles, shovels, animal drawn ploughs, oxcarts, wheelbarrows, machetes, motorcycles, and bicycles (Table 2).

The livestock and asset indices are calculated as:

$$
I=\left((1 / K) \sum_{l=1}^{K} x_{l}^{2}\right)^{1 / 2}
$$

Where $x_{l}$ corresponds with each variable included in the index.

Normalization facilitates comparison of the measures between households (Böhringer \& Jochem, 2007). The normalizing procedure applied here assigns a score to each variable included in the index based on the quartile to which a household belongs with respect to the number of units of the variable they own (Silici, 2010). For example, a household is assigned a score of 1, 2, 3, or 4 if the number of items owned by the household falls into the first, second, third, or fourth quartile. Households not owning an item used to calculate an index received a score of zero. The score is normalized by dividing the quartile level by the maximum score attainable, and then multiplying the value by 100 (for example, $3 / 4 \times 100=75$ ). Using quartiles, this procedure produces 5 possible scores a household could receive with respect to owning an item in the aggregated index; 0, 25, 50, 75, and 100 . The normalized index ranges between 0 and 100 .

The house construction index $\left(I^{C}\right)$ measures the quality and durability of materials used in the construction of a house, the physical size of the house, access to electricity, and water (Zeller, Sharma, Henry, \& Lapenu, 2006). Calculation of Equation 1 is modified following Arias and Vos (1996) because the variables used to calculate this index were categorical (Table 3). For example, if the household had electricity (a yes/no variable), it would receive a score of 100 for this component of the housing construction index, zero otherwise. Table 3 summarizes the distribution of the housing construction index components. An example calculation of this index is in Appendix A.

Table 3. House construction index scores and distribution of housing materials

\begin{tabular}{|c|c|c|c|c|}
\hline \multirow{2}{*}{ Variable } & \multicolumn{4}{|c|}{ Variable score and description } \\
\hline & 0 & 1 & 2 & 3 \\
\hline \multirow[t]{2}{*}{ Wall } & Plastic, metal sheeting, other & Plant material, mud brick & Wood & Masonry \\
\hline & (2) & $(491)$ & (7) & (46) \\
\hline \multirow[t]{2}{*}{ Floor } & Dirt & Tile, brick Cement, Other & & \\
\hline & $(453)$ & (94) & & \\
\hline \multirow[t]{2}{*}{ Roof } & Plastic sheeting, other & Plant material & Metallic sheeting, tile & \\
\hline & (195) & (190) & $(162)$ & \\
\hline \multirow[t]{2}{*}{ Wash closet } & None & External & Internal & \\
\hline & (11) & $(527)$ & $(20)$ & \\
\hline \multirow[t]{2}{*}{ Electricity } & No & Yes & & \\
\hline & (12) & $(537)$ & & \\
\hline \multirow[t]{2}{*}{ Water source } & Lake, pond, river & Pump & Piped water, water tank & \\
\hline & $(55)$ & $(491)$ & (2) & \\
\hline \multirow{2}{*}{ Number of Rooms } & 1 & 2 & 3 & $3<$ rooms \\
\hline & $(166)$ & (198) & $(104)$ & (45) \\
\hline
\end{tabular}

Note. Frequencies are in parentheses below the characteristic description.

\subsection{Multivariate Comparison of Index Scores}

The empirical model used to estimate the multivariate associations between the index scores is: 


$$
\begin{aligned}
I_{i}^{L} & =\beta_{0}^{L}+\delta^{L} \cdot c a+X_{i} \cdot \beta^{L}+\gamma^{L A} \cdot I_{i}^{A}+\gamma^{L C} \cdot I_{i}^{A C}+\varepsilon_{i}^{L} \\
I_{i}^{A} & =\beta_{0}^{A}+\delta^{A} \cdot c a+X_{i} \cdot \beta^{A}+\gamma^{A C} \cdot I_{i}^{C}+\gamma^{A L} \cdot I_{i}^{L}+\varepsilon_{i}^{A} \\
I_{i}^{C} & =\beta_{0}^{C}+\delta^{C} \cdot c a+X_{i} \cdot \beta^{C}+\gamma^{C A} \cdot I_{i}^{A}+\gamma^{C L} \cdot I_{i}^{C}+\varepsilon_{i}^{C}
\end{aligned}
$$

where $\left(\beta^{j}, \delta^{j}, \gamma^{j}\right)$ are constants to be estimated for the $i$ th houshold's $j$ th index; $\varepsilon^{j}$ is an error term with mean zero and a finite variance; $X$ is a matrix of household demographic, farm production, marketing, and community attributes; and $\mathrm{ca}$ is a variable indicating if household $i$ practiced CA. A graphical depiction of this system is in Figure 1. This regression is non-causal because the conceptual model is not presented as a full specification for predicting changes in an index, given the practice of CA. Instead, the objective of the multivariate correlational analysis is to quantify the relative associations between household characteristics, community attributes, and farming practices and household wellbeing. This exploratory approach is effective for ascertaining patterns among covariates and is especially useful when causal inference and statistical assumptions may be tenuous (Tukey, 1977; Leamer, 1983).

The null hypothesis implied by Equation 2 is that the means of the indices are not different among the groups, given household demographic attributes, farm production characteristics, and the use of CA technologies. Households with relatively more material assets may also be more likely to afford higher quality materials to build their house. Livestock ownership may also be correlated with the ownership of farm implements because equipment requirements may be greater for more diverse operations. Diversified farms raising livestock and producing maize may be able to participate in a variety of markets, earning extra income to spend on better building materials. Investment in agricultural tools and implements are expected to be correlated with the use of higher quality materials for building houses, assuming these investments are used to increase agricultural productivity and in turn generate surplus production and economic opportunity. Access to fertilizer inputs is likely to increase maize yields when applied at appropriate agronomic rates. Higher yields may increase participation in local markets, which may translate into higher household income. Farmers managing relatively more livestock would be expected to participate more frequently in livestock markets, increasing their ability to purchase better quality construction materials. The reverse direction is not anticipated with respect to use of building materials for homes and the livestock and farm implement ownership indices, but certainly possible to observe given the cross-sectional nature of the sample.

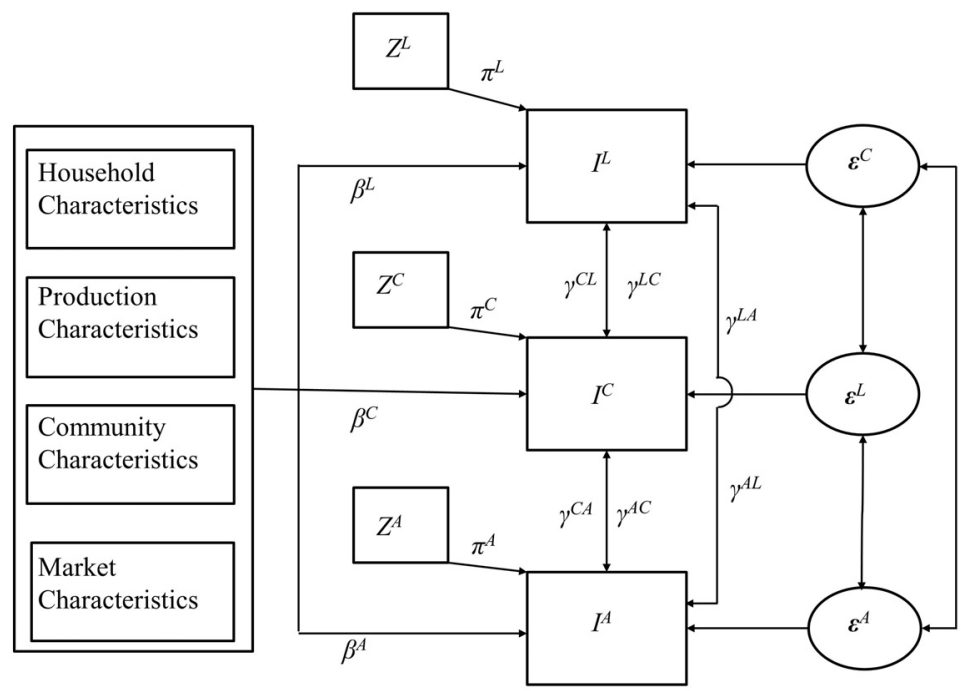

Figure 1. Graphical depiction of covariates and outcome variables

\subsection{Statistical Analysis, Model Selection, and Estimation}

Unconditional means of the indices, household characteristics and farm attributes are compared with univariate $\mathrm{t}$ tests. The null hypothesis is that the means $(\mu)$ of the groups are not different. For example, $\mu_{j}^{c a}-\mu_{j}^{g}=0, j=$ the livestock $\left(I^{L}\right)$, farm assets $\left(I^{A}\right)$, and house material quality indices $\left(I^{C}\right)$ and $g=$ households in exposed or unexposed communities. The empirical distibrutions of the indices are compared using a nonparametric 
procedure, the Kolmogorov-Smirnoff two-sample test (K-S test, Kiefer, 1959). Spearman's rank correlation ( $r$, Spearman, 1904) is used in the bivariate correlation analysis of the indices.

Model selection of Equation 2 applies a three step process considering (a) the potential endogeneity of the indices using a test suggested by Wooldridge (2004); (b) the relevance of the instruments used to test for endogeneity using Bound, Jaeger, and Baker's (1995) test; and (c) the cross-equation correlation structure of the error terms using Breusch and Pagan's (1980) test. The instruments used in (a) for $I^{A}$ and $I^{L}$ are the farmer-reported (non-market) costs of the farm tools and implements and animals. Questions about the value of house construction materials were not included in the survey. The instruments for $I^{C}$ are farmer use of credit, the number of fields rented from other farmers, household ownership of radios or televisions, and if the household head worked in a salaried position. Potential estimation procedures include Ordinary Least Squares (OLS), Seemingly Unrelated Regression (SUR; Zellner, 1962), Two Stage Least Squares (2SLS), and Three Stage Least Squares (3SLS) given the outcomes of these diagnostics.

\subsection{Covariates Included in the Multivariate Regression}

\subsubsection{Household Characteristics}

Previous studies provide little indication that household head age (agehh) would be a significant predictor of household wealth status or wellbeing (Awotide, Diagne, Wiredu, \& Ojehomon, 2012). Younger primary decision makers could inherit the wealth passed down from relatives.

Literacy and education are linked to reductions in household poverty and generally higher indicators of household wellbeing. Education is expected to be positively correlated with the wellbeing indices (Lauglo, 2001) Literacy and education rates are low in Mozambique, with illiteracy rates ranging between $70-80 \%$. School enrolment is also low, with $60-80 \%$ of individuals never attending school (Government of Mozambique Minister of State Administration, 2005). Education $(e d u c)$ is measured with a binary variable denoting whether the household head attended middle school or higher.

Female-headed households are typically poorer in Sub-Saharan Africa, own less land, and report lower levels of education (Awotide et al., 2012; Jayne et al., 2003; Government of Mozambique Minister of State Administration, 2005). Female-headed households ( $f h h)$ are expected to report lower wellbeing indices.

Household size (hhsize) is included in the empirical model. It is expected that the indices will be higher for larger households. Previous studies find that family size and wealth are correlated (Boserup, 1985). Household size includes all individuals residing in the primary residence.

The association between household composition and the wealth indicators is measured by the percentage of family members between the ages of 15 and 65 (per1565). Households with relatively more members between these ages may have greater time endowments for farm labor or working off the farm.

Incomes generated from agricultural sales (incfarm) and from wage labor (inclabor) are included in the empirical model. These shares are relative measures of income. It is expected that households earning a higher percentage of income from agricultural sales will have higher wellbeing index scores. Households earning a higher percentage of income from wage labor are expected to have lower index scores. Agriculture is the primary source of household income in the region, with labor sold primarily to other farmers (Mozambique Ministry of State Administration, 2005).

\subsubsection{Farm Characteristics}

Farm size (farmsize) is expected to be positively correlated with household wellbeing (Mather, Boughton \& Jayne, 2011). Households practicing CA operated about twice as many hectares compared with households in unexposed villages (2.13 ha and 1.19 ha, respectively). The landholdings of conventional farmers in exposed communities are intermediate, with an average of 1.74 ha.

The variable distfield is the average distance (in minutes) walking to each field managed by a household. It is hypothesized that households living farther from their fields have relatively higher index scores. Larger fields are typically located on the village periphery and primarily used to grow maize, beans, and squash. Larger fields require relatively more labor and inputs. Smaller fields are usually located near the village and used to produce vegetables.

A binary variable indicates if a household practiced CA $(c a)$. Previous research finds that fields managed with CA produce more stable or possibly higher yields (Kassam et al., 2009; Thierfelder \& Wall, 2009). Households practicing CA are hypothesized to have higher indices than their peers. This hypothesis is motivated by previous research reporting increases in crop production associated with CA production coupled with agricultural sales 
being the largest source of household income in the surveyed region. It is also hypothesized that, holding other factors constant, farmers practicing CA will have lower livestock index scores because the premium associated with residue for livestock consumption competes with use of residue to protect soil (Sitoe, 2005). The CA indicator variable is orthogonally restricted (Neter, Kutner, Nachtsheim \& Wasserman, 1996). This convention compares the mean of the index of households practicing CA to the overall mean index value of the population instead of a particular reference group. The regression estimates of equation 2 are used to test the null hypothesis that use of CA is uncorrelated with the indices; i.e., $\delta_{L}=0, \delta_{A}=0$, and $\delta_{C}=0$.

\subsubsection{Community Characteristics}

Two binary variables are included to control for community characteristics that might be associated with the indices. The first identifies respondents in Barue (barue). Barue residents are expected to have higher index scores because the climate is suited to the production of a wider variety of crops than Tete (FAO country profile, 2012). The second community characteristic indicates households residing in villages where CA had been introduced by NGO or government extension efforts but did not practice CA (exposed). Like the variable identifying households practicing CA, the exposed indicator is also orthogonally restricted; its coefficient is therefore interpreted as a level difference from the population mean of individuals belonging to each group. Households residing in exposed villages but did not practice CA are not expected to have significantly different index scores than the sample population.

Marketing characteristics include the gender of the household's primary market transactor (femmkt). The gender of the transactor is indicated with a binary variable ( 1 for female, 0 otherwise). Households where females are the primary vendors are expected to report lower index scores because female vendors are less likely to market cash crops (e.g., cotton or tobacco), and more likely to market staple crops of relatively lower value (English, 2008).

A household's marketing position is measured with a binary variable indicating whether a household is a net maize seller (netsell). Households that are net maize sellers are expected to have higher index scores because agricultural sales are the main source of household income in the surveyed regions (Government of Mozambique Minister of State Administration, 2005).

\section{Results and Discussion}

\subsection{Univariate Comparisons}

\subsubsection{Household Attributes}

The mean household head age for a farmer practicing CA is 45.5 years, as compared to 43.03 years for conventional farmers in exposed villages and 40.8 years for farmers in unexposed villages. The difference in the head of household age is significant at the $5 \%$ level for CA farmers and conventional farmers in unexposed villages (Table 4).

Individuals reported having little formal education, with only $5.6 \%$ of CA and conventional farming households in exposed communities attending middle school or higher, and approximately $7.4 \%$ of conventional farmers in unexposed communities having attended middle school. Differences in the educational attainment between groups are not significant at any conventional level.

Most respondents indicated residing in a male-headed household (77\%, Table 4). The degree to which females were the household head varied, ranging from $29 \%$ of households for conventional farmers in unexposed communities to $15 \%$ of households practicing CA. The mean difference in the household head gender for farmers using $\mathrm{CA}$ and other farmers is significant at the 5\% level. Primary adopters of CA appear to be males.

The household composition (per 1565) is similar among the groups. Approximately $50 \%$ of household members were between 15 to 65 (Table 4). For households practicing CA, the mean household size was 6.35 persons. Households practicing conventional farming in exposed and unexposed communities reported family sizes of 5.87 and 5.66, respectively. There are no significant differences in household size at the 5\% level.

Farmers practicing CA earned, on average, $82.8 \%$ of income of their agricultural income from farm sales as compared with $71.4 \%$ and $71.2 \%$ for conventional farmers in unexposed and exposed villages, respectively (significantly different at the $5 \%$ level, Table 4). Income from wage labor is not significantly different among the groups, accounting for $19.6 \%$ of all household income. 
Table 4. Means comparison of households and farm characteristics

\begin{tabular}{|c|c|c|c|c|c|c|}
\hline \multirow[b]{2}{*}{ Variable/Description } & \multirow[b]{2}{*}{ Units } & \multicolumn{2}{|c|}{ Exposed villages } & \multirow{2}{*}{$\begin{array}{l}\text { Unexposed villages } \\
\text { Conventional } \\
\text { farmers: }\end{array}$} & \multirow[b]{2}{*}{ Population } & \multirow[b]{2}{*}{$\mathrm{N}$} \\
\hline & & CA users: & $\begin{array}{l}\text { Conventional } \\
\text { farmers: }\end{array}$ & & & \\
\hline agehh/Household head (HH) age & Years & 45.5 (a) & $43.03(\mathrm{ab})$ & 40.8 (b) & 42.99 & 439 \\
\hline$f h h / \mathrm{HH}$, female & $(1=$ yes $)$ & $15.2 \%$ (a) & $21.23 \%(a b)$ & $30.62 \%(b)$ & $23 \%$ & 487 \\
\hline$e d u c / \mathrm{HH}$, primary school or higher & $(1=$ yes $)$ & $5.6 \%(a)$ & $5.6 \%(a)$ & $7.4 \%$ (a) & $7.14 \%$ & 487 \\
\hline hhsize/HH size & Persons & 6.35 (a) & 5.87 (a) & $5.66(\mathrm{a})$ & 5.93 & 485 \\
\hline per1565/HH members, age 15 - 65 & Percent & $51.26 \%(\mathrm{a})$ & $49.79 \%$ (a) & $50.39 \%$ (a) & $50.35 \%$ & 485 \\
\hline incfarm/Income, farming & Percent & $82.8 \%$ (a) & $71.4 \%(b)$ & $71.2 \%(b)$ & $74.3 \%$ & 486 \\
\hline inclabor/Income, wage labor & Percent & $14.2 \%$ (a) & $22.3 \%$ (a) & $20.4 \%$ (a) & $19.6 \%$ & 486 \\
\hline farmsize/Total field area & Hectares & $2.13(\mathrm{a})$ & 1.74 (a) & 1.19 (b) & 1.67 & 477 \\
\hline distfield/HH distance to fields & Minutes & 47.39 (a) & 54.29 (a) & 54.99 (a) & 52.45 & 485 \\
\hline femmkt/Female market transactor & (1 = yes $)$ & $24 \%$ (a) & $32.08 \%$ (a) & $39.19 \%$ (b) & 32.16 & 487 \\
\hline netsell/HH, net maize seller & $(1=$ yes $)$ & $71.2 \%$ (a) & $55.18 \%(\mathrm{~b})$ & $42.56 \%(\mathrm{c})$ & $55.37 \%$ & 485 \\
\hline
\end{tabular}

Notes. Means followed by the same letter in the same row are not significantly different at the $5 \%$ level (t-test).

Key. Exposed villages; villages where conservation agriculture had been introduced by NGO of government extension efforts. Unexposed villages; villages where conservation agriculture had not been promoted by NGO or government extension efforts.

\subsubsection{Farm Characteristics}

The difference in land holdings between farmers practicing CA and conventional farmers in unexposed villages, as well as the difference between conventional farmers in exposed and unexposed villages, is significant at the 5 $\%$ level (Table 4). Average distance to fields was not different among the groups (52.45 minutes) (Table 4).

\subsubsection{Community Characteristics}

Among households participating in maize markets, the difference in females as the primary transactor is significant at the 5\% level for CA farmers and conventional farmers in unexposed villages, with females the primary vendor in $24 \%$ of the households practicing CA as compared to $39 \%$ for conventional farmers in unexposed villages (Table 4). Females are the primary market transactors in approximately $32 \%$ of conventional farming households in exposed communities. Men are ostensibly the primary decision makers concerning maize marketing, but women in households using CA appear to be less likely to make maize marketing decisions than women in households that do not practice CA. The extent to which these differences are systematic is left for future research.

Farmers practicing CA were more likely to participate in maize markets as vendors, with $71.2 \%$ of CA farmers selling maize, compared to $55.18 \%$ and $42.56 \%$ of conventional farmers in exposed and unexposed communities selling maize, respectively (Table 4). The difference in market participation rates is also significant at the 5\% level.

\subsubsection{Index Scores}

Examination of the cumulative distributions (CDFs) of the indices suggests that households practicing CA had relatively more livestock compared to their community peers and farmers living in other villages (Figure 2). Less clear were differences in livestock ownership between farmers not practicing CA in villages where CA had been introduced and farmers in other communities. The relative ordering of the CDFs between the groups for the farm tool and implement index was similar to the livestock index. At all probability levels above $5 \%$, the asset ownership index was higher for farmers who practiced CA. The respective CDFs of farmers in exposed communities practicing conventional agriculture and farmers in unexposed communities crossed at several probability levels below the median values, making it difficult to discern if one group was more endowed than another in terms of farm tool and implement ownership. At all probability levels below $95 \%$, farmers in communities where CA had been promoted by extension efforts used better quality materials to construct their 
houses.
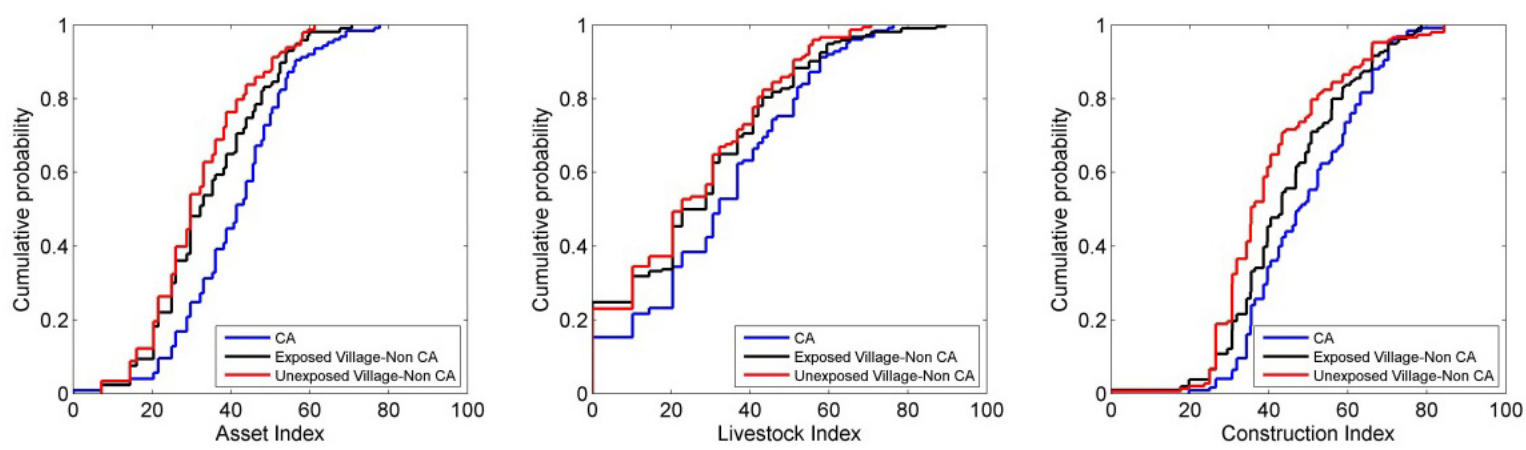

Figure 2. Cumulative distributions of the livestock, farm implement, and housing materials indices

Key: $\mathrm{CA}=$ conservation agriculture users in exposed communities.

Table 5. Descriptive statistics of the asset, livestock, and house construction indices

\begin{tabular}{llll}
\hline Index/Subgroup: & Mean & Standard error & $\mathrm{N}$ \\
\hline Livestock index: & & & 125 \\
Conservation agriculture farmers, exposed communities & 32.07 (a) & 1.84 & 214 \\
Conventional farmers, exposed communities & 26.61 (b) & 1.46 & 148 \\
Conventional farmers, unexposed communities & 24.86 (b) & 1.60 & 125 \\
Asset index: & & & 214 \\
Conservation agriculture farmers, exposed communities & 41.07 (a) & 1.25 & 148 \\
Conventional farmers, exposed communities & 34.54 (b) & 0.94 & 1.04 \\
Conventional farmers, unexposed communities & 31.93 (b) & & 125 \\
House construction index: & 49.40 (a) & 1.25 & 214 \\
Conservation agriculture farmers, exposed communities & 44.72 (b) & 1.02 & 148 \\
Conventional farmers, exposed communities & 40.67 (c) & 1.22 & \\
Conventional farmers, unexposed communities & & & \\
\hline
\end{tabular}

Notes. Indices range from $0-100$. Means followed by the same letter in the same column of an index are not significantly different at the $5 \%$ level ( $\mathrm{t}$ test).

The livestock index average for farmers practicing CA was significantly higher than the livestock index of other farmers at the 5\% level (Table 5). However, the mean difference of this index between conventional farmers in exposed and unexposed farmers was not significant. The nonparametric comparison of the livestock index cumulative distributions based on the K-S two-sample test support these results at the $10 \%$ level of significance.

Households growing maize and various livestock appear to be more likely to experiment with CA. On average, farmers practicing CA owned more farm implements and tools compared with conventional farmers in exposed and unexposed communities (Table 5). Farmers practicing CA may have access to a wider array of agricultural tools and implements through their engagement with projects promoting CA.

The house material quality index was different among all groups (Table 5). Farmers practicing CA used better quality materials to build their houses compared with farmers using conventional agronomic practices in exposed and unexposed communities. Comparisons of the $I^{C}$ and $I^{A}$ distributions using the K-S test support the means comparison results determined by the two-sample $t$ tests at the $5 \%$ level.

Bivariate analysis of the indices suggests they are significantly correlated (Spearman's rank correlation coefficient; $r, \mathrm{P}<0.01$ ). The relationships are linear (Figure 3). The correlation between the house material quality $\left(I^{C}\right)$ and farm implement ownership indices $\left(I^{4}\right)$ ranged between $r=0.33$ (conventional farmers, exposed 
villages) and $r=0.46$ (conservation agriculture users). The livestock and house material quality index were moderately correlated across the groups as well, with Spearman's rank correlations of $r=0.33$ and 0.37 for farmers in exposed villages. For farmers practicing conventional agriculture in unexposed villages, the correlation between the $I^{L}$ and $I^{C}$ indices was weaker $(r=0.30)$. The relationship between the livestock and farm implement ownership indices was stronger across the three groups, with the rank correlation coefficient ranging between $r=0.52$ and 0.62 . The level differences are discernible with respect to the cumulative density functions and sample means of the respondents practicing conventional and CA (Table 5 and Figure 2), but the magnitude and direction of the associations between these variables are relatively similar across the groups.
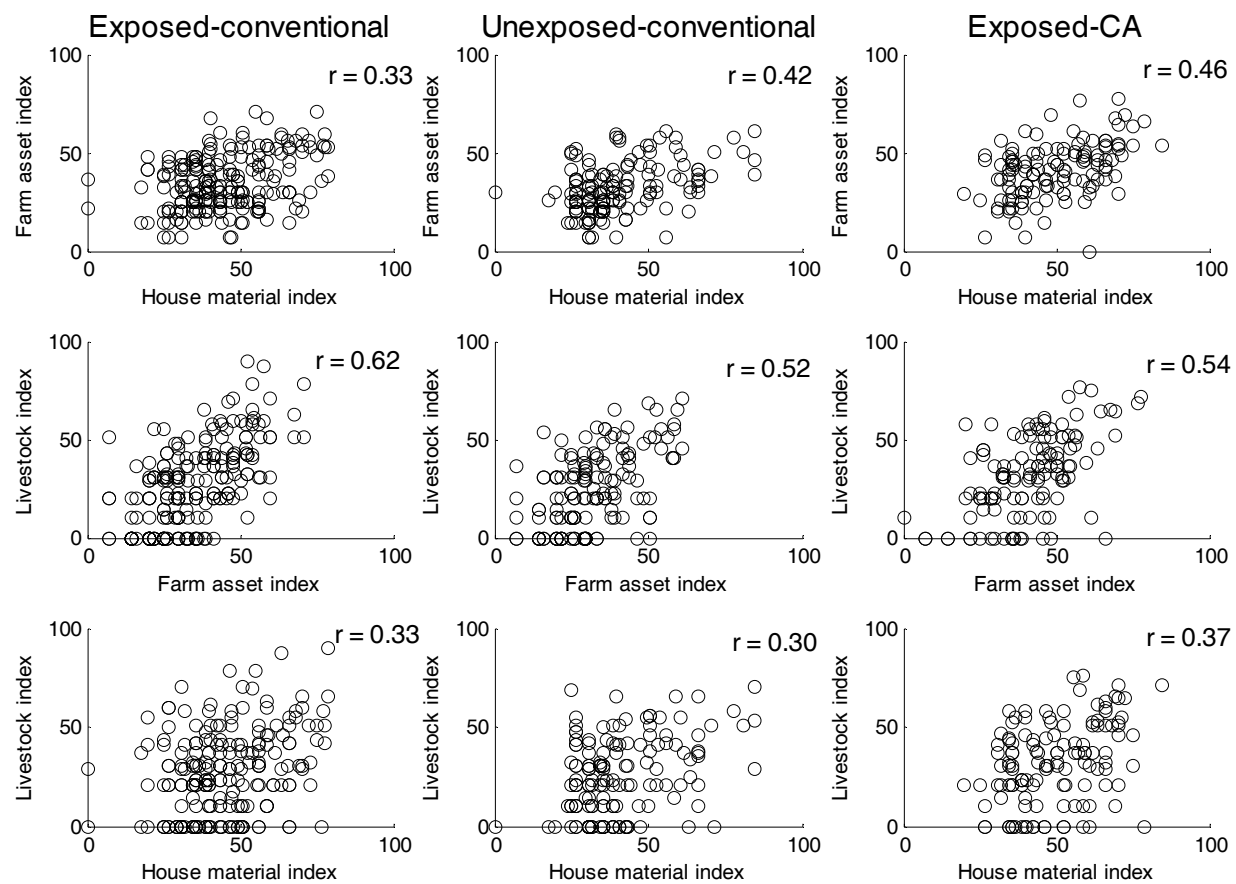

Figure 3. Wellbeing indices and farmer group correlations

\subsection{Multivariate Regression Results}

Bound et al.'s $\mathrm{F}$ test suggests the instruments used in Wooldridge's test for exogeneity are relevant (Table 6). Wooldridge's test for exogeneity does not suggest the indexes included as covariates in the regressions are endogenous (Table 6). Finally, the Breusch-Pagan test indicated that the error terms of the index equations are correlated $\left(\chi^{2}=150, P<0.0001\right.$, degrees of freedom $\left.=2\right)$. Variance inflation factors were less than 10 , suggesting that multicollinearity was not inflating standard error estimates (O'Brien, 2007). Given these results, SUR is used to estimate equation system 2 . The empirical model explains $71 \%$ of the variation in the index scores according to the system weighted $R^{2}$ (McElroy, 1977) (Table 7).

\subsection{Index Correlations}

The indices appearing as explanatory variables are highly correlated in each equation with the dependent variable indices $(\mathrm{P}<0.0001)$ (Table 7). The indices explained $42 \%$ of the system weighted $R^{2}$ (not reported in the tables). Increases in one dimension of household wellbeing are positively correlated with increases in others. A 1-unit increase in the asset index is associated with a 0.93 and 0.65 point increase of the livestock and house materials construction indices, respectively. All else equal, a 1-unit increase in the livestock index is associated with an increase in the asset and house construction indices of 0.303 and 0.154 , respectively. A 1 -unit increase in the construction index is associated with an increase in the asset and livestock indices of 0.30 and 0.15 , respectively. 
Table 6. Model selection results

\begin{tabular}{llll}
\hline Variable & Asset index & Livestock index & Construction index \\
\hline Asset index & F value $(\mathrm{P}>\mathrm{F})$ & F value $(\mathrm{P}>\mathrm{F})$ & F value $(\mathrm{P}>\mathrm{F})$ \\
Livestock index & $0.45(0.636)$ & $\cdot$ & $\cdot$ \\
House construction index & $\cdot$ & $0.84(0.4337)$ & $\cdot$ \\
$\mathrm{N}$ & $\cdot$ & $\cdot$ & $0.56(0.5726)$ \\
$\mathrm{df}$ & 418 & 418 & 418 \\
Bound et al.'s test of instrument relevance & 16 & 16 & 16 \\
Asset index & $10.25(0.0001)$ & $\cdot$ & $\cdot$ \\
Livestock index & $\cdot$ & $9.02(0.0001)$ & $\cdot$ \\
House construction index & $\cdot$ & $\cdot$ & $2.55(0.0079)$ \\
$\mathrm{N}$ & 418 & 418 & 418 \\
$\mathrm{df}$ & 32 & 32 & 32 \\
Breusch and Pagan test results for correlation between error terms & & \\
$\chi^{2}$ & 150.337 & & \\
$\mathrm{P}$ value & 0.0001 & & \\
$\mathrm{~N}$ & 418 & & \\
$\mathrm{df}$ & 2 & & \\
\hline
\end{tabular}

\subsection{Household Demographic Variables and Indices}

Demographic variables are significantly correlated with the indices. Holding other factors constant, the farm tool and implement index for households headed by females is 5.07 lower than male-headed households $(\mathrm{P}<0.0001)$ (Table 7). Education is also positively associated with the asset index at the $10 \%$ level. Asset index scores were higher for larger households; an increase in household size of 1 individual corresponds with an increase of 0.884 points for this index $(\mathrm{P}<0.01)$. Conversely, family size is negatively correlated with the house construction index; a 1-person increase in family size corresponds with a 0.52 point decrease in this index $(\mathrm{P}=0.096)$. The percentage of household income derived from farming as well as off farm labor are negatively correlated with the house construction index $(\mathrm{P}=0.008$ and $\mathrm{P}=0.038$, respectively). A $1 \%$ increase in the proportion of household income corresponds with a 1.2-point decrease in the house construction index, and a $1 \%$ increase in household income from wage labor is associated with a 0.95 -point decrease in the house construction index.

Farm size is positively associated with the livestock index $(\mathrm{P}=0.055)$; an increase in land holdings by 1 -ha is associated with a 0.842 increase in the livestock index score. Field distance from the house is correlated with an increase in the farm tool and implement index; for every one minute increase in the field distance from the respondent's house, this index increases by $0.019(\mathrm{P}=0.045)$. Larger fields are generally located farther from village centers. Households farming larger plots tend to be wealthier.

Barue residents have significantly higher farm tool and implement and livestock indices, with the tool and implement index scores 5.84 points higher than households in Tete $(\mathrm{P}<0.0001)$. The livestock index was 5.01 points higher for Barue residents compared to households in Tete $(\mathrm{P}=0.036)$. Barue residents had house construction index scores that are 9.48 points less than Tete residents $(\mathrm{P}<0.0001)$. Households in villages where CA extension efforts had occurred, but that did not practice CA had asset index scores 1.09 lower than the population average $(\mathrm{P}=0.097)$. 
Table 7. Seemingly unrelated regression results

\begin{tabular}{|c|c|c|c|c|c|c|}
\hline \multirow[b]{2}{*}{ Variable } & \multicolumn{2}{|c|}{ Asset index $\left(I^{A}\right)$} & \multicolumn{2}{|c|}{ Livestock index $\left(I^{L}\right)$} & \multicolumn{2}{|c|}{ Construction index $\left(I^{C}\right)$} \\
\hline & Estimate & $\operatorname{Pr}>T$ & Estimate & $\operatorname{Pr}>T$ & Estimate & $\operatorname{Pr}>T$ \\
\hline Intercept & -1.094 & 0.8010 & -21.006 & 0.0021 & 38.203 & $<.0001$ \\
\hline agehh & 0.0032 & 0.9398 & 0.0571 & 0.4525 & 0.0162 & 0.7766 \\
\hline$f h h$ & -5.0726 & $<.0001$ & 2.7090 & 0.2314 & 2.5986 & 0.1130 \\
\hline educ & 3.2072 & 0.2393 & -3.5780 & 0.4679 & -2.6186 & 0.3890 \\
\hline hhsize & 0.8841 & 0.0001 & -0.3270 & 0.4088 & -0.5234 & 0.0962 \\
\hline per1565 & 0.0331 & 0.2353 & 0.0068 & 0.9002 & -0.0426 & 0.2631 \\
\hline incfarm & 0.1646 & 0.6073 & 0.7308 & 0.1684 & -1.1903 & 0.0080 \\
\hline inclabor & 0.2049 & 0.5371 & -0.0150 & 0.9765 & -0.9496 & 0.0383 \\
\hline$c a$ & 1.1846 & 0.1549 & -3.7110 & 0.0102 & 2.5629 & 0.0192 \\
\hline farmsize & 0.1219 & 0.7570 & 0.8423 & 0.0550 & 0.2179 & 0.5174 \\
\hline distfield & 0.0191 & 0.0459 & -0.0230 & 0.2150 & -0.0159 & 0.2729 \\
\hline exposed & -1.0900 & 0.0979 & -0.0850 & 0.9387 & 0.9733 & 0.3025 \\
\hline barue & 5.8499 & 0.0000 & 5.0149 & 0.0362 & -9.4865 & $<.0001$ \\
\hline femmkt & -1.0110 & 0.3288 & 0.2282 & 0.9005 & -0.4502 & 0.7544 \\
\hline netsell & -0.2490 & 0.8110 & 0.5026 & 0.7747 & -0.1374 & 0.9277 \\
\hline $\operatorname{Assets}\left(I^{A}\right)$ & . & . & 0.9252 & $<.0001$ & 0.6527 & $<.0001$ \\
\hline Livestock $\left(I^{L}\right)$ & 0.3036 & $<.0001$ & . & . & 0.1548 & 0.0005 \\
\hline Construction $\left(I^{C}\right)$ & 0.3000 & $<.0001$ & 0.2167 & 0.0008 & . & . \\
\hline System $R^{2}$ & & & 0.71 & & & \\
\hline $\mathrm{N}$ & & & 419 & & & \\
\hline
\end{tabular}

Notes. probability values ( $\operatorname{Pr}>\mathrm{T})$ are based on Davidson and MacKinnon's (1993) jackknife standard errors.

\subsection{Use of Conservation Agriculture and the Wellbeing Indices}

Households practicing CA had higher house construction index scores and lower livestock index scores. Differences between farm tool and implement ownership indices were not significant. The house construction index was 2.56 points higher for $\mathrm{CA}$ users than the population mean $(\mathrm{P}=0.019)$. However, households practicing CA reported livestock index scores that were 3.7 points lower than the population average $(P=0.01)$. This finding may be attributed to the trade-off between retaining agricultural residues on fields and managing livestock. Farmers practicing CA are usually instructed by extension personnel to retain crop residue on fields, competing directly with the use of crop residues for forage. This result is consistent with previous research, which found that households using CA tend to manage less livestock (Silici, 2010).

\section{Conclusions}

This study contributes to research on conservation agriculture and its association with socioeconomic status by determining the extent to which household wellbeing is correlated with the use of CA. A set of indices was developed and applied to proxy household wellbeing based on primary survey data. The wellbeing indices were compared across three groups using univariate comparisons and multivariate regression: (a) CA users; (b) households using conventional agronomic practices in villages where CA was practiced but had not adopted CA, and (c) households practicing conventional agriculture in villages where extension efforts promoting CA had not occurred.

Household income is difficult to measure in many rural populations, often depending on respondent recall or best guesses. Data availability, the expense of collecting household survey information over time, respondent attrition, and difficulties establishing counterfactual cases between communities of technology adopters and non-adopters further complicates these challenges. Because of these inherent difficulties, this analysis only focused on the 
association between CA and the wellbeing of smallholder farmers in Mozambique using household survey data. The analysis does not purport to establish causality between the use of CA and household wellbeing. We cannot immediately discern if households using CA whose wellbeing appears to be higher than their cohorts were already better off before they started using the technology, or if the agronomic advantages typically associated with CA increased maize production, food security, and opportunities to participate in cash markets. Such an analysis would require a counterfactual case, and contacting the same households for more than a single period. Reliable measures of changes in income, wage earnings, agricultural profits and more generally wealth, following technology adoption, are also difficult to generalize across a population because respondents may be unable to recollect or unwilling to divulge such information. Researchers resort to income and wealth proxies hypothesized to correlate with household wellbeing; an alternative applied in this research with these caveats in mind. Despite these limitations, it is possible to make assertions about the level differences and ceteris paribus comparisons of the resources enjoyed by users of CA and their contemporaries.

The univariate analysis suggests that households practicing CA are relatively more endowed with farm assets and livestock than conventional farmers, and have access to better building materials for their homes. The multivariate analysis was generally consistent with the univariate findings. Holding other factors constant, households practicing CA had lower livestock index scores. This was expected given the competing nature of conservation agriculture (residue management) and animal grazing. Conditioning on household, farm, and regional attributes matters in terms of the conclusions drawn about the level difference of CA on the indices analyzed here.

This research is instructive for practitioners focused on addressing agricultural productivity issues and soil erosion/fertility concerns through the smallholder farmer adoption of conservation agriculture. The household attributes analyzed here suggest a situation where conservation agriculture farmers are better off than the population ceteris paribus, and may therefore be better positioned to bear the risk associated with the adoption of new technologies. To deepen and broaden adoption of CA across socioeconomic classes, strategies that improve access for resource-constrained households, including those headed by females, should be developed and employed.

Future research needs to be conducted at the onset of extension efforts and over an appropriate period of time to ascertain the medium and long term causal effects of conservation agriculture adoption on household wellbeing. Findings from this study suggest that for CA to be successful, additional knowledge about the interactions between livestock and cropping systems is needed. Livestock consume one main component of CA-year round residue cover - $\mathrm{a}$ factor that provides resilience to the agronomic production system by protecting soil resources from erosion. Without understanding further the interaction effects on smallholder African farming systems the likelihood of long-term CA success will be diminished.

\section{Acknowledgements}

This research was sponsored by the United States Agency for International Development, Sustainable Agriculture and Natural Resource Management Collaborative Research and Support Program (USAID SANREM-CRSP). The co-authors thank Drs. Michael Wilcox, Forbes Walker, and Christian Thierfelder, Mr. Ivan Cuvaca, Mr. Nyasha Chipunza, and Total Land Care for their collaboration and help with the household survey.

\section{References}

Almeida, J., Rucker, J., Gemo, H., \& Launchange, C. (2009). Desenvolvimento Rural: percepções e perspectivas no Brasil e em Mocambique (p. 267). Porto Alegre, Brazil: Programa de Pós-Graduação em Desenvolvimento Rural/Universidade Federal do Rio Grande do Sul. Retrieved August 12, 2013, from http://www.ufrgs.br/pgdr/livros/outras_publicacoes/ebooks/01_ebook_PGDR.pdf

Arias, E., \& Vos, S. (1996). Using housing items to indicate socioeconomic status: Latin America. Social Indicators Research, 38, 53-80. http://dx.doi.org/10.1007/BF00293786

Awotide, B., Diagne, A., Wiredu, A., \& Ojehomon, V. (2012). Wealth status and agricultural technology adoption among smallholder rice farmers in Nigeria. OIDA International Journal of Sustainable Development, 5, 97-108.

Böhringer, C., \& Jochem, P. E. (2007). Measuring the immeasurable - A survey of sustainability indices. Ecological Economics, 63, 1-8. http://dx.doi.org/10.1016/j.ecolecon.2007.03.008

Boehlje, M. D., \& Eidman, V. R. (1984). Farm Management. New York, NY: John Wiley \& Sons. 
Boserup, E. (1985). Economic and demographic interrelationships in sub-Saharan Africa. Population and Development Review, 11, 383-397. http://dx.doi.org/10.2307/1973245

Bound, J., Jaeger, D. A., \& Baker, R. M. (1995). Problems with instrumental variables estimation when the correlation between the instruments and the endogenous explanatory variable is weak. Journal of the American Statistical Association, 90, 443-450. http://dx.doi.org/10.1080/01621459.1995.10476536

Breusch, T. S., \& Pagan, A. R. (1980). The Lagrange multiplier test and its applications to model specification in econometrics, The Review of Economic Studies, 47, 239-253. http://dx.doi.org/10.2307/2297111

Davidson, R., \& MacKinnon, J. G. (1993). Estimation and inference in econometrics. New York, Oxford Univesity Press.

Ekboir, J. M. (2002). Developing no-till packages for small-scale farmers. In J. M. Ekboir (Ed.), World Wheat Overview and Outlook 2000-2001 (pp. 1-37). CIMMYT, Mexico, D. F.

English, A. (2008). Determinants of Liberian farmgate cocoa prices (Master's Thesis). University of Tennessee, Knoxville.

Erenstein, O. (2003). Smallholder conservation farming in the tropics and sub-tropics: A guide to the development and dissemination of mulching with crop residues and cover crops. Agriculture, Ecosystems and Environment, 100, 17-37. http://dx.doi.org/10.1016/S0167-8809(03)00150-6

Eswaran, H., Lal, R., \& Reich, P. F. (2001). Land degradation: An overview. In Degradatio, E. M. Bridges, I. D. Hannam, L. R. Oldeman, T. Pening, S. J. Scherr, \& S. Sompatpanit (Eds.), Responses to Land. New Delhi, Oxford Press. Retrived October 20, 2014, from http://soils.usda.gov/use/worldsoils/papers/land-degradation-overview.html

Evans-Pritchard, E. E. (1953). The sacrificial role of cattle among the Nuer. Journal of the International African Institute, 23(3), 181-198. http://dx.doi.org/10.2307/1156279

Falcão, M. P. (2009). Política agrícola e política agrária: Experiência Moçambicana. In J. Almeida, J. Rucker, H. Gemo, \& C. Launchange (Eds.), Desenvolvimento Rural: Percepções e Perspectivas no Brasil e em Moçambique (p. 267). Porto Alegre, Brazil: Programa de Pós-Graduação em Desenvolvimento Rural/Universidade Federal do Rio Grande do Sul. Retrieved August 12, 2013, from http://www.ufrgs.br/pgdr/livros/outras_publicacoes/ebooks/01_ebook_PGDR.pdf

FAO. (2012). Mozambique country profile. Retrieved August 1, 2013, from $\mathrm{ftp} / / / \mathrm{ftp}$.fao.org/docrep/fao/010/a1250e/annexes/CountryReports/Mozambique.pdf

FAO. (2001a). The economics of conservation agriculture. Food and Agriculture Organization. Rome, Italy.

FAO. (2001b). Conservation agriculture: Case studies in Latin America and Africa. Soils Bulletin (No. 78). Rome, Italy.

Filmer, D., \& Pritchett, L. H. (2001). Estimating wealth effect without expenditure data - or tears: An application to educational enrollments in states of India. Demography, 38, 115-132. http://dx.doi.org/10.1353/dem.2001.0003

Giller, K. E., Witter, E., Corbeels, M., \& Tittonell, P. (2009). Conservation agriculture and smallholder farming in Africa: The heretic's view. Field Crops Research, 114, 23-34. http://dx.doi.org/10.1016/j.fcr.2009.06.017

Giller, K. E. (2012). No silver bullet for African soil problems. Nature, 485, 41. http://dx.doi.org/10.1038/485041c

Government of Mozambique. (2005). Overview of the districts of Angonia, Barue, Tsangano. Maputo: Ministry of State Administration/Government of Mozambique. Retrieved August 1, 2013, from http://www.portaldogoverno.gov.mz/Informacao/distritos

Grabowski, P. (2011). Qualitative assessment of conservation agriculture in the Angonia highlands of Mozambique: perspectives from smallholder farmers. Regional Conservation Agriculture Symposium for Southern Africa, 8-10 February 2011, Johannesburg, South Africa. Retrieved August 12, 2013, from www.iiam.gov.mz/documentos/isfm/CA_Avaliacao_qualitativa_AC_planalto_Angonia.pdf

Guto, S. N., Pypers, P., Vanlauwe, B., de Ridder, N., \& Giller, K. E. (2011). Tillage and vegetative barrier effects on soil conservation and short-term economic benefits in the Central Kenya highlands. Field Crops Research, 122, 85-94. http://dx.doi.org/10.1016/j.fcr.2011.03.002

Heltberg, R., \& Tarp, F. (2002). Agricultural supply response and poverty in Mozambique. Food Policy, 27, 
103-124. http://dx.doi.org/10.1016/S0306-9192(02)00006-4

Howard, J., Kelly, V., Maredia, M., Stepanek, J., \& Crawford, E. W. (1999). Progress and problems in promoting high external-input technologies in sub-Saharan Africa: The Sasakawa Global 2000 experience in Ethiopia and Mozambique. American Agricultural Economics Association Annual Meeting, Nashville, Tennessee, 8-11 August, 1999.

Howe, L. D., Hargreaves, J. R., \& Huttly, S. R. (2008). Issues in the construction of wealth indices for the measurement of socio-economic position in low-income countries. Emerging Themes in Epidemiology, 5, 1-14. http://dx.doi.org/10.1186/1742-7622-5-3

Jayne, T. S., Yamano, T., Weber, M. T., Tschirley, D., Benfica, R., Chapoto, A., \& Zulu, B. (2003). Smallholder income and land distribution in Africa: Implications for poverty reduction strategies. Food Policy, 28, 253-275. http://dx.doi.org/10.1016/S0306-9192(03)00046-0

Johansen, C., Haque, M. E., Bell, R. W., Thierfelder, C., \& Esdaile, R. J. (2012). Conservation agriculture for small holder rainfed farming: Opportunities and constraints of new mechanized seeding systems. Field Crops Research, 132, 18-32. http://dx.doi.org/10.1016/j.fcr.2011.11.026

Kassam, A. H., Friedrich, T., Shaxson, F., \& Pretty, J. (2009). The spread of conservation agriculture: Justification, sustainability and uptake. International Journal of Agricultural Sustainability, 7, 292-320. http://dx.doi.org/10.3763/ijas.2009.0477

Kiefer, J. (1959). K-Sample analogues of the Kolmogorov-Smirnov and Cramér-von Mises tests. Annals of Mathematical Statistics, 30, 420-447. http://dx.doi.org/10.1214/aoms/1177706261

Knowler, D., \& Bradshaw, B. (2007). Farmers' adoption of conservation agriculture: A review and synthesis of recent research. Food Policy, 32, 25-48. http://dx.doi.org/10.1016/j.foodpol.2006.01.003

Lauglo, J. (2002). Engaging with adults: The case for increased support to adult basic education in Sub-Saharan Africa. World Bank, Africa Region, Report No. 22193 (p. 47). Washington, DC: World Bank. Retrieved August $1, \quad 2013, \quad$ from http://documents.worldbank.org/curated/en/2001/02/1121219/engaging-adults-case-increased-support-adult -basic-education-sub-saharan-africa

Leamer, E. E. (1983). Let's take the 'con' out of econometrics. The American Economic Review, 73, 31-43.

Lohr, S. L. (2010). Sampling: design and analysis (2nd ed.). Pacific Grove, California: Brooks/Cole Publishing Co.

Mather, D., Boughton, D., \& Jayne, T. S. (2011). Smallholder heterogeneity and maize market participation in Southern and Eastern Africa: Implications for investment strategies to increase marketed food staple supply (Working Paper No. 118473). Michigan State University International Development, East Lansing, MI.

Mazvimavi, K., \& Twomlow, S. (2009). Socioeconomic and institutional factors influencing adoption of conservation farming by vulnerable households in Zimbabwe. Agricultural Systems, 101, 20-29. http://dx.doi.org/10.1016/j.agsy.2009.02.002

McElroy, M. B. (1977). Goodness of fit for seemingly unrelated regressions: Glahn's $\mathrm{R}^{2} \mathrm{y}, \mathrm{x}$ and Hooper's $\mathrm{r}^{2}$. Journal of Econometrics, 6, 381-387. http://dx.doi.org/10.1016/0304-4076(77)90008-2

Montgomery, M. R., Gragnolati, M., Burke, K. A., \& Paredes, E. (2000). Measuring living standards with proxy variables. Demography, 37, 155-174. http://dx.doi.org/10.2307/2648118

Morris, M. L. (2007). Fertilizer use in African agriculture: Lessons learned and good practice guidelines. World Bank Publications, Geneva, Switzerland. http://dx.doi.org/10.1596/978-0-8213-6880-0

Moser, C., \& Felton, A. (2007). The construction of an asset index measuring asset accumulation in Ecuador. Chronic Poverty Research Centre Working Paper No. 87 (p. 20). Retrieved July 27, 2013, from $\mathrm{http} / /$ www.chronicpoverty.org/publications/details/the-construction-of-an-asset-index-measuring-asset-accu mulation-in-ecuador $1 / \mathrm{ss}$

Morris, M., Kelly, V. A., Kopicki, R. J., \& Byerlee, D. (2007). Fertilizer use in African agriculture: Lessons learned and good practice guidelines. World Bank, Report No. 39037. World Bank, Washington, DC. Retrieved July 26, 2013, from https:/openknowledge.worldbank.org/handle/10986/6650

Neter, J., Kutner, M. H., Nachtsheim, C. J., \& Wasserman, W. (1996). Applied Linear Statistical Models. Chicago, IL: Richard D. Irwin Pub. 
Ngwira, A. R., Aune, J. B., \& Mkwinda, S. (2012). On-farm evaluation of yield and economic benefit of short term maize legume intercropping systems under conservation agriculture in Malawi. Field Crops Research, 132, 149-157. http://dx.doi.org/10.1016/j.fcr.2011.12.014

Ngwira, A. R., Thierfelder, C., Eash, N., \& Lambert, D. M. (2013). Risk and maize-based cropping systems for smallholder Malawi farmers using conservation agriculture technologies. Experimental Agriculture, 49(3), 4830-503.

O’Brien, R. M. (2007). A caution regarding rules of thumb for variance inflation factors. Quality \& Quantity, 41, 673-690. http://dx.doi.org/10.1007/s11135-006-9018-6

Paulo, J. C. T. (2007). Manual de Agricultura de Conservacao para técnicos e agricultores. H300 Development Consult, Vienna Austria.

Silici, L. (2010). Conservation agriculture and sustainable crop intensification in Lesotho. Integrated Crop Management (Vol.10, p. 66). Rome, Italy: Food and Agriculture Organization of the United Nations.

Silici, L., Ndabe, P., Friedrich, T., \& Kassam, A. (2011). Harnessing sustainability, resilience and productivity through CA: the case of Likoti in Lesotho. International Journal of Agricultural Sustainability, 9, 137-144. http://dx.doi.org/10.3763/ijas.2010.0555

Sitoe, T. A. (2005). Agricultura Familiar em Moçambique. Estratégias de Desenvolvimento Sustentável-Perspectives for a Rural Development Model (p. 31). Retrieved August 1, 2013, from http://www.sarpn.org/documents/d0001749/Agricultura_Mocambique_June2005.pdf

Spearman, C. (1904). The proof and measurement of association between two things. American Journal of Psychology, 15, 72-101. http://dx.doi.org/10.2307/1412159

Taimo, J. P., \& Calegari, A. (2007). Manual de Agricultura de Conservação para Técnicos e Agricultores (p. 113). Vienna, Austria: H3000 Development Consult.

Thierfelder, C., \& Wall, P. C. (2009). Effects of conservation agriculture techniques on infiltration and soil water content in Zambia and Zimbabwe. Soil and Tillage Research, 105, 217-227. http://dx.doi.org/10.1016/j.still.2009.07.007

Thierfelder, C., Chisui, J. L., Gama, M., Cheesman, S., Jere, Z. D., Bunderson, W. T., ... Rusinamhodzi, L. (2013). Maize-based conservation agriculture systems in Malawi: Long-term trends in productivity. Field Crops Research, 142, 47-57. http://dx.doi.org/10.1016/j.fcr.2013.01.004

Thierfelder, C., Mwila, M., \& Rusinamhodzi, L. (2013). Conservation agriculture in eastern and southern provinces of Zambia: Long-term effects on soil quality and maize productivity. Soil and Tillage Research, 126, 246-258. http://dx.doi.org/10.1016/j.still.2012.09.002

Thierfelder, C., Cheesman, S., \& Rusinamhodzi, L. (2013). Benefits and challenges of crop rotations in maize-based conservation agriculture (CA) cropping systems of southern Africa. International Journal of Agricultural Sustainability, 11, 108-124. http://dx.doi.org/10.1080/14735903.2012.703894

Tukey, J. W. (1977). Exploratory data analysis. Reading, Massachusetts: Addison-Wesley.

Uaiene, R. N. (2008). Determinants of Agricultural Technical Efficiency and Technology Adoption in Mozambique (Doctoral dissertation). Purdue University Department of Agricultural Economics, West Lafayette: Purdue University.

Vyas, S., \& Kumaranayake, L. (2006). Constructing socio-economic status indices: How to use principal components analysis. Health Policy and Planning, 21, 459-468. http://dx.doi.org/10.1093/heapol/czl029

Wooldridge, J. M. (2004). Introductory econometrics: A modern approach. Cincinnati, OH: South-Western College Pub.

Zeller, M., Sharma, M., Henry, C., \& Lapenu, C. (2006). An operational method for assessing the poverty outreach performance of development policies and projects: Results of case studies in Africa, Asia, and Latin America. World Development, 34, 446-464. http://dx.doi.org/10.1016/j.worlddev.2005.07.020

Zellner, A. (1962). An efficient method of estimating seemingly unrelated regression equations and tests of aggregation bias. Journal of the American Statistical Association, 57, 348-368. http://dx.doi.org/10.1080/01621459.1962.10480664 


\section{Appendix}

Appendix A. Example calculation of the livestock index for a household

\begin{tabular}{llll}
\hline Variable & Units owned & $\begin{array}{l}\text { Quartile membership for } \\
\text { ownership of this animal }\end{array}$ & Score \\
\hline Chicken & 9 & 3 & 75 \\
Pig & 0 & 0 & 0 \\
Goat & 2 & 2 & 50 \\
Cattle & 1 & 1 & 25 \\
Duck & 0 & 0 & 0 \\
Rabbit & 4 & 2 & 50 \\
\hline
\end{tabular}

Based on the example data, the livestock index for a household is 43.30 .

\section{Copyrights}

Copyright for this article is retained by the author(s), with first publication rights granted to the journal.

This is an open-access article distributed under the terms and conditions of the Creative Commons Attribution license (http://creativecommons.org/licenses/by/3.0/). 